\title{
First record of Dero (Aulophorus) bimagnasetus Harman (Oligochaeta) from Brazil and habitat characteristics
}

\author{
Campitelli-Ramos, $R .^{a *}$, Lucca, JV. ${ }^{b}$, Oliveira, LLD. ${ }^{a}$, Marchese, MR. ${ }^{c}$ and Rocha, $O .^{b}$ \\ aPrograma de Pós-Graduação em Ciências, Departamento de Hidraúlica e Saneamento, \\ Escola de Engenharia de São Carlos, Universidade de São Paulo - USP, \\ Avenida Trabalhador Sãocarlense, 400, Centro, CEP 13566-590, São Carlos, SP, Brazil \\ bDepartamento de Ecologia e Biologia Evolutiva, Universidade Federal de São Carlos - UFSCar, \\ Rod. Washington Luis, Km 235, CP 676, CEP 13565-905, São Carlos, SP, Brazil \\ 'Instituto Nacional de Limnología - INALI, Consejo Nacional de Investigaciones Científicas y Técnicas - CONICET, \\ Universidad Nacional del Litoral - UNL, Cidade Universitária, 3000, Santa Fé, Argentina \\ *e-mail: raphael@unescnet.br
}

Received July 31, 2012 - Accepted February 22, 2013 - Distributed May 31, 2014

(With 4 figures)

\begin{abstract}
Annelid worms represent a significant part of freshwater benthic communities worldwide and Oligochaeta is a particularly species-rich group. Dero (A) bimagnasetus (Naididae) previously found and described from a small marsh in Surinam in 1974, has now been found for the first time in Barra Lake, MG, Brazil. Due to the scarce biological data and absence of ecological information in the literature regarding this species we are presenting morphological information on the specimens obtained and the physical and chemical characteristics of the habitat they were found. This species occurred only in the littoral zone of Barra Lake, in muddy, low oxygen, low conductivity and low organic matter sediment. The four individuals collected ranged 3.17-4.15 mm total length; $0.25-0.26 \mathrm{~mm}$ body width and $0.16-0.21 \mathrm{~mm}^{3}$ total volume. Considering the present anthropic pressures on freshwater biota and fast biodiversity losses worldwide it is now recognized that attention must be paid to low abundance species and the urgency for preservation of their habitats.
\end{abstract}

Keywords: Oligochaeta, taxonomy, new record, freshwater biota, benthos.

\section{Primeiro registro de Dero (Aulophorus) bimagnasetus Harman (Oligochaeta) do Brasil e notas ecológicas}

\section{Resumo}

Vermes anelídeos representam uma parte significativa das comunidades de água doce em todo o mundo e Oligochaeta é um grupo particularmente rico em espécies. Dero $(A)$ bimagnasetus (Naididae) havia sido encontrado e descrito em um pequeno pântano no Suriname em 1974, e agora também coletado na lagoa Barra, MG, Brasil. Devido ao baixo número de espécimes coletados e à ausência de informações ecológicas sobre esta espécie, estamos apresentando informações sobre a morfometria dos espécimes obtidos e as características físicas e químicas de seu habitat. Esta espécie ocorreu apenas na região litorânea da lagoa da Barra, em sedimento lamacento e com pouca matéria orgânica, baixa concentração de oxigênio e baixa condutividade elétrica na água. Os quatro indivíduos encontrados tiveram $3,17-4,15 \mathrm{~mm}$ de comprimento total; 0,25-0,26 mm de largura e 0,16-0,21 $\mathrm{mm}^{3}$ de biovolume. Considerando as atuais pressões antrópicas sobre a biota de água doce e as rápidas perdas de biodiversidade em todo o mundo, é agora reconhecido que muita atenção deve ser dada às espécies pouco abundantes e que é urgentemente necessário preservar seus habitats.

Palavras-chave: Oligochaeta, taxonomia, novo recorde, biota de água de doce, bentos.

\section{Introduction}

Aquatic Oligochaeta form an important and particularly rich-species component of benthic and pleustonic invertebrate aquatic environments around the world. There has been a considerable advance in taxonomical research for this group, but this has not so far been accompanied by ecological studies. The understanding of biological diversity in relation to its origin and maintenance requires a great deal of ecological information and there is nowadays a consensus that, in order to conserve biodiversity, both taxonomical and ecological studies must be pursued at a much faster pace.

Dero (Aulophorus) Schmarda, 1861, is well represented among the Oligochaeta occurring in Brazil, with 8 species recorded. Only 1 species, $D$. (A.) furcatus Müller, has a 
cosmopolitan distribution and in Brazil it has been recorded in seven states: 1) Paraná state, in Patos Lake, in the municipality of Taquarussu by Montanholi-Martins and Takeda (2001); in Ivinhema River, between the municipalities of Taquarussu and Jateí, by Montanholi-Martins and Takeda (2001) and Behrend et al. (2009); in Baía River, in the municipality of Batayporã by Behrend et al. (2009); 2) São Paulo state, in Pinheiros and Jardim Europa districts, in the municipality of São Paulo by Marcus (1943); in ornamental fish breeding ponds, associated with the gastropod Pomacea bridgesii Reeve, in the municipality of Araraquara by Gorni and Alves (2006); in Tietê River, in the municipality of Barra Bonita by Suriani et al. (2007); in Tietê River, in the municipality of Bariri by Pamplin et al. (2005); 3) Mato Grosso state, in Rio Negro River (Pantanal biome) by Takeda et al. (2000); 4) Pernambuco state, in the municipality of Cabo by Du Bois-Reymond Marcus (1947); in the municipality of Bom Jardim by Marcus (1944) and Du Bois-Reymond Marcus (1947); in the municipality of Mercês by Du BoisReymond Marcus (1947); in the municipality of Salgadinho by Du Bois-Reymond Marcus (1947); 5) Pará state, in the municipality of Fordlândia by Du Bois-Reymond Marcus (1947, 1949a, b); in Cururú River, an indigenous land of Munduruku (a tributary of Tapajós River), in the municipality of Jacareacanga by Du Bois-Reymond Marcus (1947); in Acará River, in the municipality of Óbidos by Du BoisReymond Marcus (1947,1949b); in the south of Belém city by Du Bois-Reymond Marcus (1947); in the municipality of Itaituba by Du Bois-Reymond Marcus (1947); and in the municipality of Humaitá by Marcus (1943); Du BoisReymond Marcus (1947, 1949a, b); 6) Minas Gerais state, in São Pedro stream, in the municipality of Juiz de Fora by Stephan (2007); in Piumhi River, in the municipality of Piumhi by Suriani-Affonso et al. (2011); Rio Grande do Sul state, in a rice field channels, in the municipality of Mostarda by Stenert (2009).

Another 3 species, D. (A.) lodeni Brinkhurst, D. (A.) vagus Leidy and $D$. (A.) hymanae Naidu, can be considered widely distributed. In Brazil, $D$. (A.) lodeni was recorded in 3 states: 1) São Paulo state, in Tietê River, in the municipality of Bariri by Pamplin et al. (2005) and Suriani et al. (2007); in Tietê River, in the municipality of Barra Bonita by Suriani et al. (2007); in Infernão Lake (Ecological Station of Jataí), in the municipality of Luís Antônio by Correia and Trivinho-Strixino (1998) and Trivinho-Strixino et al. (2000); 2) Pará state, in the municipality of Fordlândia by Marcus (1942); Du Bois-Reymond Marcus (1947, 1949a); in Cupari River, in the municipality of Óbidos by Marcus (1942); Du Bois-Reymond Marcus (1947, 1949a, b); 3) Paraná state, in Baía River, in the municipality of Baytaporã by Behrend et al. (2009).

$D$. (A.) vagus was recorded in three states, only: 1) Minas Gerais state, in Timboré Lake (at the natural lakes system of Middle Rio Doce Valley), in the municipality of Dionísio by Campitelli-Ramos (2008); 2) Rio Grande do Sul state, in a rice field channel, in the municipality of Mostarda by Stenert (2009); 3) Mato Grosso do Sul state, in Rio Negro River (Pantanal biome) by Takeda et al.
(2000). D. (A.) hymanae was recorded only in São Paulo state in Tietê River, in the municipality of Promissão by Suriani et al. (2007).

The remaining 4 species are endemic to the Neotropical region: D. (A.) bimagnasetus, $D$. (A.) costatus Du BoisReymond Marcus and D. (A.) carteri Stephenson, or to the American continents: $D$. (A.) borellii Michaelsen. According to Harman (1974), D. (A.) is one of the oldest taxa among Neotropical Oligochaeta and this region may be its centre of dispersal, and also a centre of origin. In Brazil, D. (A.) bimagnasetus was only recorded in Minas Gerais state, in Barra Lake (at the natural lake system of Middle Rio Doce Valley), in the municipality of Dionísio by Campitelli-Ramos (2008).

Dero (A.) hymanae and D. (A.) costatus were recorded only in São Paulo state: in Pinheiros River, in the municipality of São Paulo by Marcus $(1942,1943)$ and Du Bois-Reymond Marcus (1944); in Lagoa Dourada Reservoir associated with the sponge Metania spinata Carter and with the submerged macrophytes Mayaca fluviatilis (Mayacaceae) and Najas sp. (Najadaceae), in the municipality of Itirapina, by Gorni and Alves (2008).

D. (A.) carteri was recorded in 4 states in Brazil: 1) São Paulo state, in the Emas Reservoir, in the municipality of Pirassununga by Marcus (1943); 2) Piauí state, in the Caicós Reservoir by Marcus (1944) and Du Bois-Reymond Marcus (1947); 3) Pernambuco state, in the municipality of Recife, in Capoeira and São Bento district by Marcus (1944); in the municipality of Goiana by Marcus (1944); 4) Pará state, in the municipality of Fordlândia by Du BoisReymond Marcus (1947, 1949a, b); in Cururú River, in the municipality of Jacareacanga by Du Bois-Reymond Marcus (1947); in São Manuel River, in the municipality of Óbidos by Du Bois-Reymond Marcus (1947), in Cuminá River by Marcus (1942); Du Bois-Reymond Marcus (1947), in Salgado Lake by Marcus (1942) and Du Bois-Reymond Marcus (1947); in Alemquer river by Marcus (1942) and Du Bois-Reymond Marcus (1947).

D. (A.) borellii was recorded in 6 states in Brazil: 1) São Paulo state, in Santa Clara stream, in the municipality of Araraquara by Alves and De Lucca (2000); in Infernão Lake, in the municipality of Luís Antônio by TrivinhoStrixino et al. (2000); 2) Mato Grosso do Sul state, in Negro River (Pantanal Biome) by Takeda et al. (2000); 3) Mato Grosso state by Michaelsen (1900); 4) Pará state, in Tapajós river by Du Bois-Reymond Marcus (1947); in the municipality of Fordlândia by Du Bois-Reymond Marcus (1947, 1949a, b); in Cururú river, in the municipality of Jacareacanga by Du Bois-Reymond Marcus (1947); in the municipality of Santarém by Marcus (1942) and Du Bois-Reymond Marcus (1947); in Trombetas River, in the municipality of Óbidos by Marcus (1942) and Du Bois-Reymond Marcus (1947), in Acará river by Du Bois-Reymond Marcus (1947, 1949b), in Cuminá River by Marcus (1942) and Du Bois-Reymond Marcus (1947), in Salgado Lake by Marcus (1942); Du Bois-Reymond Marcus (1947), in Alemquer River by Marcus (1942) and Du Bois-Reymond Marcus (1947); 5) Amazon state, in 
the municipality of Macaés by Du Bois-Reymond Marcus (1947, 1949b); 6) Minas Gerais state, in São Pedro Stream, in the municipality of Juiz de Fora by Stephan (2007).

In this paper we report the first occurrence of Dero $(A$.) bimagnasetus in Brazil, describing some of its morphological characteristics and the environmental conditions of the habitat in which this species was found. Before the present record, this species was only recorded within the Neotropical region in a small marsh located in the Surinam (Harman, 1974), its type locality.

\section{Material and Methods}

Barra Lake (see in Figure 1) is a relatively large lake in the Middle Rio Doce Valley, Minas Gerais state, Brazil (1948'00.2" S; 42 $37^{\circ}$ ' 17.3" W). The lake is surrounded by Eucalyptus forest from reforestation, mixed with native Atlantic forest regrowth.

Sampling was carried out at 5 sites on the lake, 1 in the limnetic and 4 in the littoral zone, on one sampling date, March 03, 2004, in the morning (08:00 h - 11:00 h). Geographical coordinates were recorded with a GPS Garmin 130.

Water $\mathrm{pH}$, electrical conductivity and dissolved oxygen parameters were measured at 3 depths in the water column and on the bottom with the multi-probe sensor Horiba U-10. Water samples for the analysis of total phosphorus and nitrogen concentrations were collected at the surface layer with a Van Dorn bottle, stored in polyethylene bottles and frozen shortly thereafter. The total nitrogen and total phosphorus concentrations were determined in the laboratory, according to the procedures described in Mackereth et al. (1978).

Sediment samples were taken with a Van Veen grab $\left(337 \mathrm{~cm}^{2}\right)$ for both benthic macroinvertebrates and sediment particle size analysis. The organic matter content of the sediment was determined as in Buchman and Brady (1979) and sand, silt and clay fractions were determined as described by Suguio (1973), and this information was used to classify sediment texture (Camargo et al., 1987).

Two sediment samples were taken in each sampling site. Samples were sieved through a net of $0.21 \mathrm{~mm}$ mesh. The retained material was preserved in $8 \%$ formaldehyde solution. In the laboratory, organisms were sorted out and identified under a Zeiss Stemi SV 6 stereo-microscope and Zeiss Axioskop 2 Plus microscope, using specialised literature, mainly the taxonomical keys of Righi (1984) and Brinkhurst and Marchese (1989).

Specimens were photographed and measured in a Zeiss Axiocam $\mathrm{HCr}$ microscope with an image acquisition system. Individual biovolumes were calculated from linear dimensions using the cylinder equation (Sun and Liu, 2003).

\section{Results}

Dero (A.) bimagnasetus (Figure 2) specimens were found among the macroinvertebrates collected at site 4, one of the four littoral sites sampled in Barra Lake. Since this is the first record of this species in Brazilian freshwater environments, a general characterisation of the physical and chemical conditions in site 4 is presented (as shown in Table 1).

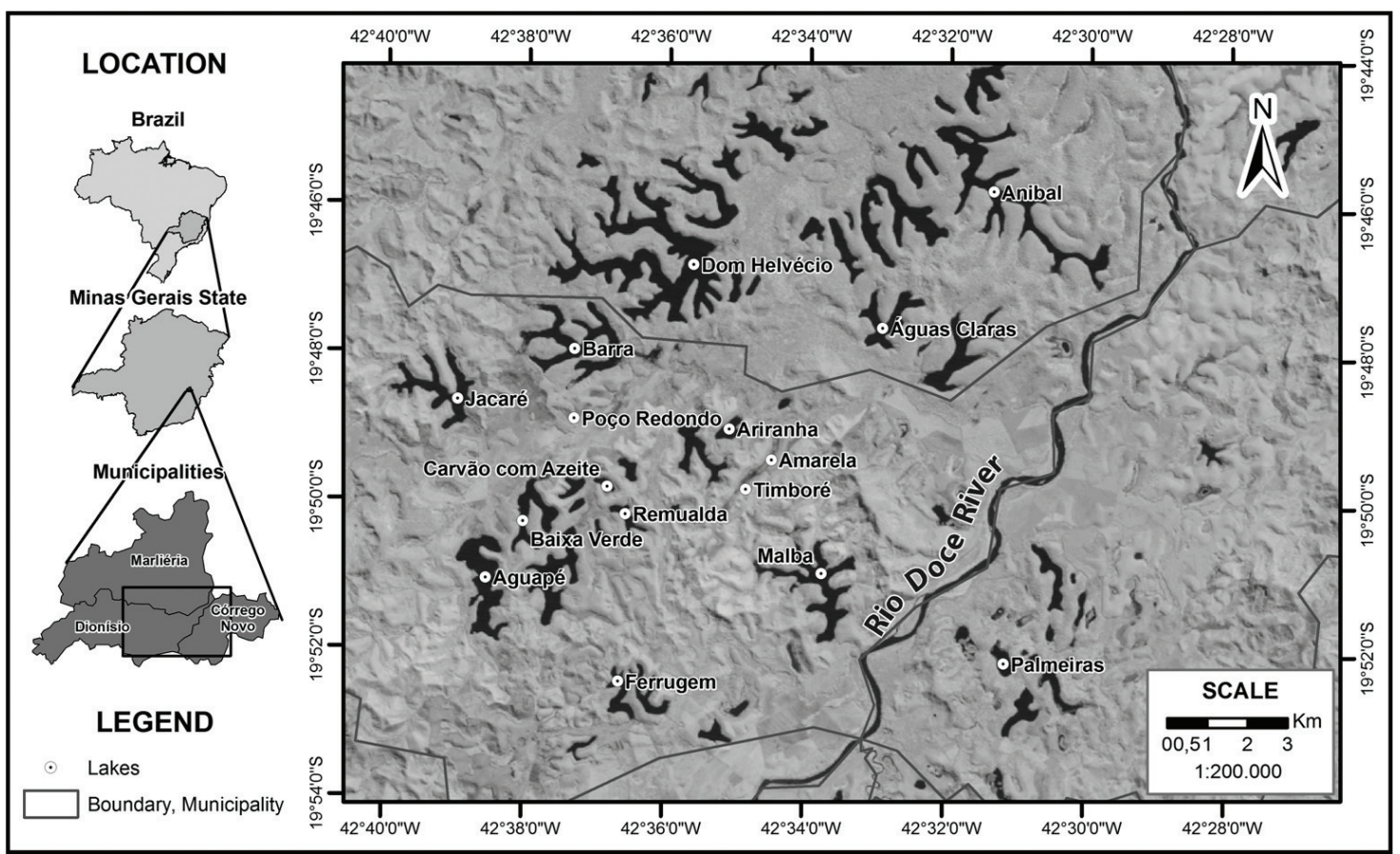

Figure 1. Schematic drawing and aerial view showing Barra Lake location in Minas Gerais state, Brazil. Source: LANDSAT 5 TM, National Institute for Space Research (INPE). http://www.inpe.br/ 
The water $\mathrm{pH}$ was nearly neutral, and the conductivity was low. The dissolved oxygen concentration at point 4 was significantly lower than at the other sites. Also, there was a dense stand of macrophytes (Eleocharis sp., Nymphaea sp. and Utricularia sp.) at this site, not seen at any other sampling site in the littoral zone of the lake (CampitelliRamos, 2008). In the previous record of this species in Surinam, D. (A.) bimagnasetus was first recorded among rotting plant debris (Harman, 1974). However, in Barra Lake, $D$. (A.) bimagnasetus was collected from muddy sediment with little organic matter, as shown in Table 2.

Only 4 individuals of this species were found in the littoral zone of Barra lake, and linear dimensions and

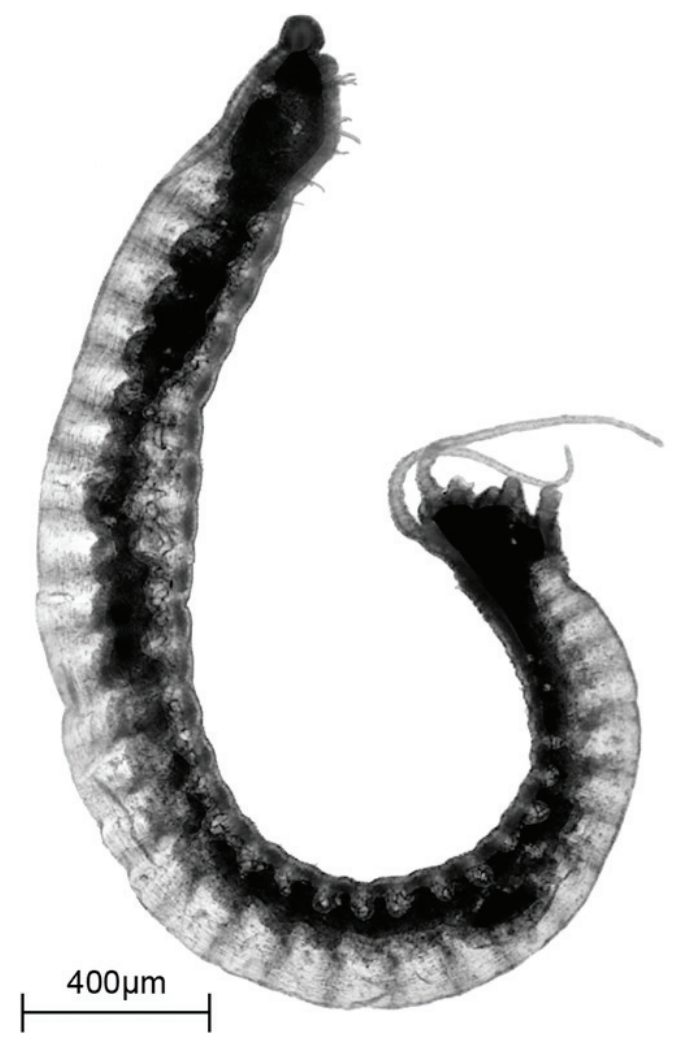

Figure 2. General view of Dero (Aulophorus) bimagnasetus under optical microscope at 50 times magnification. biovolumes of the specimens are presented (as shown in Table 3). The total length varied from 3.17 to $4.15 \mathrm{~mm}$; width from 0.25 to $0.32 \mathrm{~mm}$ and biovolume from 0.16 to $0.35 \mathrm{~mm}^{3}$.

\section{Discussion}

D. (A.) bimagnasetus was among the less abundant species sampled in the Barra Lake, which could be the result of a small number of samples taken, instead of an actual species rarity. They were also among the smallest sized organisms in the benthic assemblages when compared with other macroinvertebrates collected in the sediment at site 4 .

The distinctive morphological feature of $D$. (A.) bimagnasetus is the occurrence in the ventral bundles of III of a single giant chaetae and 1 or 2 giant chaetae in the ventral bundle of IV (see in Figure 3 and Figure 4). Among the Naidinae, this character also appears in other species, e.g., Pristina aequiseta Bourne. However, in the genus Dero no other species possess such giant chaetae (Brinkhurst and Wetzel, 1984).

$D$. (A.) bimagnasetus shares with its congeners $D$. (A.) furcatus, $D$. (A.) borellii, $D$. (A.) lodeni, D. (A.) hymanae and $D$. (A.) indicus Naidu, the presence of a

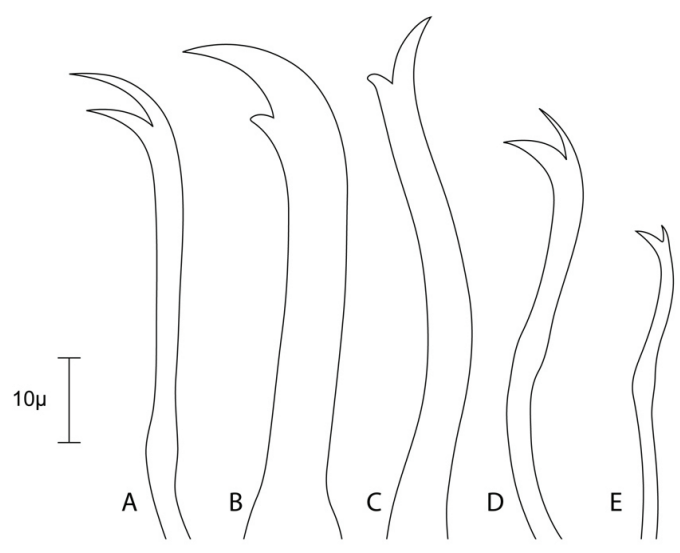

Figure 3. Dero (Aulophorus) bimagnisetus setae. A: normal ventral seta of II; B: giant ventral seta of III; C: giant ventral seta of IV; D: normal posterior ventral seta; E: needle seta. Modified from Harman (1974).

Table 1. Values of $\mathrm{pH}$, electrical conductivity (Cond), temperature (Temp) and concentrations of dissolved oxygen (DO), total nitrogen $(\mathrm{N})$ and total phosphorus (P) in the water column at site 4 (S: $19^{\circ} 48^{\prime} 002^{\prime}$, W: $\left.42^{\circ} 37^{\prime} 173^{\prime \prime}\right)$ in the littoral zone of Barra Lake, Middle Rio Doce Valley, Minas Gerais State, Brazil. X: Average; SD: standard deviation.

\begin{tabular}{|c|c|c|c|c|c|c|c|c|}
\hline \multirow[b]{2}{*}{ Site } & \multicolumn{8}{|c|}{ March, 2004} \\
\hline & \multicolumn{2}{|c|}{$\begin{array}{c}\text { Depth } \\
\text { (m) }\end{array}$} & pH & $\begin{array}{c}\text { Cond } \\
\left(\mu S \mathrm{~cm}^{-1}\right)\end{array}$ & $\begin{array}{c}\text { OD } \\
\left(\mathrm{mg} \mathrm{L}^{-1}\right)\end{array}$ & $\begin{array}{c}\text { Temp } \\
\left({ }^{\circ} \mathrm{C}\right)\end{array}$ & $\begin{array}{c}\text { N (total) } \\
\left(\mu g \mathrm{~L}^{-1}\right)\end{array}$ & $\begin{array}{l}P \text { (total) } \\
\left(\mu \mathrm{g} \mathrm{L}^{-1}\right)\end{array}$ \\
\hline \multirow{3}{*}{$\begin{array}{c}\text { Barra Lake } \\
\text { (Site 4) }\end{array}$} & Surface & 0.0 & 7.17 & 30 & 3.02 & 27.8 & 379.32 & 12.16 \\
\hline & Middle & 1.1 & 6.44 & 29 & 2.44 & 28.6 & - & - \\
\hline & Bottom & 2.2 & 6.42 & 30 & 2.84 & 28.5 & - & - \\
\hline $\begin{array}{c}\text { Mean } \\
\text { SD }\end{array}$ & - & - & $\begin{array}{c}6.68 \\
\pm 0.43\end{array}$ & $\begin{array}{l}29.67 \\
\pm 0.58\end{array}$ & $\begin{array}{c}2.77 \\
\pm 0.30\end{array}$ & $\begin{array}{r}28.30 \\
\pm 0.44\end{array}$ & - & - \\
\hline
\end{tabular}


Table 2. Sediment fractions (sand, silt and clay), percent organic matter and textural classification of sediment at site 4, Barra Lake, Middle Rio Doce Valley, Minas Gerais State, Brazil, where individuals of Dero (Aulophorus) bimagnasetus were found.

\begin{tabular}{cccccccc}
\hline & \multicolumn{6}{c}{ Barra Lake (March, 2004) } \\
\cline { 2 - 8 } Sampling Site & $\begin{array}{c}\text { Bottom } \\
\text { organic } \\
\text { matter (\%) }\end{array}$ & $\begin{array}{c}\text { Coarse } \\
\text { sand (\%) }\end{array}$ & $\begin{array}{c}\text { Medium } \\
\text { sand (\%) }\end{array}$ & $\begin{array}{c}\text { Fine sand } \\
(\%)\end{array}$ & $\begin{array}{c}\text { Silt } \\
(\%)\end{array}$ & Clay (\%) & Texture \\
\hline 4 & 2.04 & 3.67 & 22.12 & 20.29 & 17.97 & 35.94 & Muddy \\
\hline
\end{tabular}

Table 3. Length, width and biovolume of four individuals of Dero (Aulophorus) bimagnasetus found in the sediment collected at site 4, littoral region of Barra Lake, Middle Rio Doce Valley, Minas Gerais State, Brazil. SD: standard deviation.

\begin{tabular}{|c|c|c|c|}
\hline \multicolumn{4}{|c|}{ Barra Lake (Site 4) March/2004 } \\
\hline Individuals & Length (mm) & Width (mm) & Biovolume $\left(\mathrm{mm}^{3}\right)$ \\
\hline 1 & 4.15 & 0.26 & 0.21 \\
\hline 2 & 4.27 & 0.32 & 0.35 \\
\hline 3 & 3.67 & 0.27 & 0.21 \\
\hline 4 & 3.17 & 0.25 & 0.16 \\
\hline Mean & 3.82 & 0.28 & 0.23 \\
\hline SD & \pm 0.51 & \pm 0.032 & \pm 0.082 \\
\hline
\end{tabular}

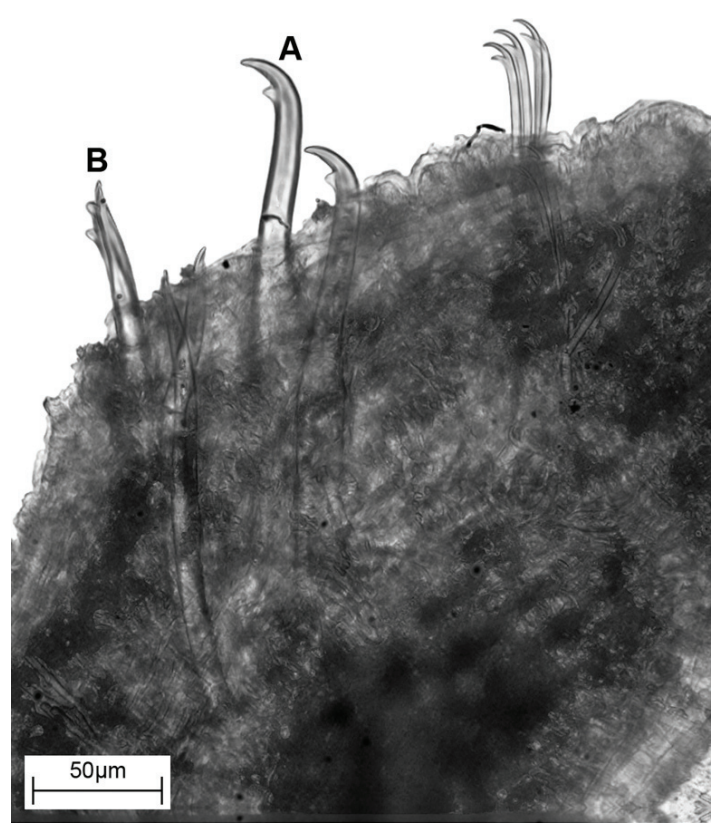

Figure 4. Detailed view of Dero (Aulophorus) bimagnasetus giant setae located at segments III (A) and VI (B) (pair), under optical microscope.

bifid or pectinate needle chaetae, beginning at segment V. However, according to Harman (1974), who described this species, the presence of giant chaetae in the ventral bundles indicates a possible sexual reproductive mode, not previously found in this genus. The name of this species is therefore related to the very large ventral chaetae on segments III and IV.

The fact that up to now $D$. (A.) bimagnasetus had been found only in Surinam and now in Southeastern Brazil, suggests that this might be a low abundance species. Considering the increasing anthropic pressure on freshwater habitats and consequent biodiversity losses by habitat destruction, a great attention should be paid to this species and its habitat, in order to preserve it, as well the all other components of benthos community in Barra Lake. We also expect that reporting its occurrence in Brazil and its distinctive features may contribute to finding it in other localities, and to get a deeper knowledge of its ecological requirements.

Acknowledgements - The authors would like to thank the Brazilian Federal Research and Education Council (CNPq) for the financial support for the research (PROBIO/MMA, Covenant 952/02) and scholarship (process number: 134419/2006-5) and FAPESP for the scholarship (process number: 06/54264-5). We also thank Ricardo Milanetti Degani for his help with map elaboration and image edition.

\section{References}

ALVES, RG. and DE LUCCA, JV., 2000. Oligochaeta (Annelida: Clitellata) como indicador de poluiçăo orgânica em dois córregos pertencentes a Bacia do Ribeirăo do Ouro Araraquara (Săo PauloBrasil). Brazilian Journal of Ecology, vol. 4, no. 1-2, p. 112-117.

BEHREND, RDL., FERNANDES, SEP., FUJITA, DS. and TAKEDA, AM., 2009. Eight years of monitoring aquatic Oligochaeta from the Baía and Ivinhema Rivers. Brazilian Journal of Biology, vol. 69, no. 2, supl. 0, p. 559-571. http://dx.doi.org/10.1590/S151969842009000300011. PMid:19738963

BRINKHURST, RO. and WETZEL, MJ., 1984. Aquatic Oligochaeta of the world: Supplement. A catalogue of new freshwater species, descriptions and revisions. Canada: Fisheries and Oceans. p. 44-101. Canadian Technical Report of Hydrography and Ocean Sciences, no. 44.

BRINKHURST, RO. and MARCHESE, MR., 1989. Guia para la identificación de oligoquetos acuáticos continentales de Sud 
$y$ Centroamerica. 2th ed. Santo Tomé: Associación de Ciencias Naturales del Litoral.

BUCHMAN, HO. and BRADY, NC., 1979. Natureza e propriedades do solo. 5th ed. Rio de Janeiro: Freitas Bastos.

CAMARGO, MN., KLAMT, E. and KAUFFMAN, JH., 1987. Classificação de solos usada em levantamentos pedológicos no Brasil. Sociedade Brasileira de Ciência do Solo, Campinas, vol. 12, p. 11-33.

CAMPITELLI-RAMOS, R.,2008. Estudo da composição taxonômica e da densidade de macroinvertebrados bentônicos no sistema de lagoas naturais do vale do médio Rio Doce (MG), com ênfase na espécie de molusco exótica Melanoides tuberculata (Müller, 1774). São Carlos: Universidade de São Paulo. 146 p. Dissertação de mestrado em Ciências da Engenharia Ambiental.

CORREIA, LCS. and TRIVINHO-STRIXINO, S., 1998. Macroinvertebrados da rizosfera de Scirpus cubensis na Lagoa do Infernão (Estação Ecológica de jataí-SP): Estrutura e função. Acta Limnologica Brasiliensia, vol. 10, no. 1, p. 37-47.

DU BOIS-REYMOND MARCUS, E., 1944. Notes on fresh-water Oligochaeta from Brazil. Comununicaciones Zoologicas del Museo de Historia Natural de Montevideo, vol. 1, no. 20, p. 1-8.

DU BOIS-REYMOND MARCUS, E., 1947. Naidids and tubificids from Brazil. Comunicaciones Zoologicas del Museo de Historia Natural de Montevideo, vol. 2, no. 44, p. 1-20.

DU BOIS-REYMOND MARCUS, E., 1949a. Further notes on naidids and tubificids from Brazil. Comunicaciones Zoologicas del Museo de Historia Natural de Montevideo, vol. 3, no. 51, p. 1-15.

DU BOIS-REYMOND MARCUS, E., 1949b. A new tubificid from the Bay of Montevideo. Comunicaciones Zoologicas del Museu de Historia Natural de Montevideo, vol. 3, no. 56, p. 1-6.

GORNI, GR. and ALVES, RD., 2006. Naididae (Annelida, Oligochaeta) associated with Pomacea bridgesii (Reeve) (Gastropoda, Ampullaridae). Revista Brasileira de Zoologia, vol. 23, no. 4, p. 1059-1061. http://dx.doi.org/10.1590/S0101-81752006000400011.

GORNI, GR. and ALVES, RG., 2008. Naididae species (Annelida: Oligochaeta) associated with the sponge Metania spinata (Carter, 1881) (Porifera: Metaniidae) from a southeastern Brazilian reservoir. Acta Limnologica Brasiliensia, vol. 20, no. 3, p. 261-263.

HARMAN, WJ., 1974. The Naididae (Oligochaeta) of Surinam. Zoologische Verhandelingen., vol. 133, no. 1, p. 1-36.

MACKERETH, FJH., HERON, J. and TALLING, FJ., 1978. Water analysis: some revised methods for limnologists. Freshwater Biological Association Scientific Publication. Kendall: Titus Wilson e Sons. Freshwater Biological Association Scientific Publication, no. 36 .

MARCUS, E., 1942. Sobre algumas Tubificidae do Brasil. Boletim de Zoologia, vol. 25, no. 6, p. 153-253.

MARCUS, E., 1943. Sobre Naididae do Brasil. Boletim de Zoologia, vol. 32, no. 7, p. 3-181.
MARCUS, E., 1944. Sobre Oligochaeta límnicos do Brasil. Boletim de Zoologia, vol. 43, no. 8, p. 5-101.

MICHAELSEN, W., 1900. Oligochaeta. Berlin: R. Friedländer und Sohn. Das Tierreich, no. 10.

MONTANHOLI-MARTINS, MC. and TAKEDA, AM., 2001. Spatial and temporal variations of Oligochaetes of the Ivinhema River and Patos Lake in the Upper Paraná River Basin, Brazil. Hydrobiologia, vol. 463, no. 1-3, p. 197-205. http://dx.doi. org/10.1023/A:1013163927814.

PAMPLIN, PAZ., ROCHA, O. and MARCHESE, M., 2005. Riqueza de espécies de Oligochaeta (Anellida, Clitellata) em duas represas do rio Tietê (São Paulo). Biota Neotropica, vol. 5, no. 1, p. 63-70. http://dx.doi.org/10.1590/S1676-06032005000100007.

RIGHI, G., 1984. Oligochaeta. Manual de Identificação de Invertebrados Límnicos do Brasil, Brasília, CNPq, 48 p.

SUGUIO, K., 1973. Introdução à Sedimentologia. São Paulo: Editora Edgar Blucher Ltda.

SUN, J. and LIU, D., 2003. Geometric models for calculating cell biovolume and surface area for phytoplankton. Journal of Plankton Research, vol. 25, no. 11, p. 1331-1346. http://dx.doi. org/10.1093/plankt/fbg096.

SURIANI, AL., FRANÇA, RS., PAMPLIN, PA., MARCHESE, M., LUCCA, JV. and ROCHA, O., 2007. Species richness and distribution of oligochaetes in six reservoirs on Middle and low Tietê River (SP, Brazil). Acta Limnologica Brasiliensia, vol. 19, no. 4, p. 415-426.

SURIANI-AFFONSO, AL., FRANÇA, RS., MARCHESE, M. and ROCHA, O., 2011. Environmental factors and benthic Oligochaeta (Annelida, Clitellata) assemblages in a stretch of the Upper São Francisco River (Minas Gerais state, Brazil). Brazilian Journal of Biology, vol. 71, no. 2, p. 437-446. PMid:21755161.

STEPHAN, NNC., 2007. Distribuição Espacial e Temporal dos insetos e Oligochaeta aquáticos da Sub-Bacia do córrego São Pedro. Juiz de Fora: Universidade Federal de Juiz de Fora. 61 p. Dissertação de Mestrado em Ciências Biológicas, Comportamento e Biologia Animal.

STENERT, C., 2009. Estrutura da comunidade de macroinvertebrados aquáticos em arrozais do Rio Grande do Sul. São Carlos: Universidade Federal de São Carlos. 205 p. Tese de Doutorado em Ecologia e Recursos Naturais.

TAKEDA, AM., PEREIRA, MCF. and BARBOSA, FAR., 2000. Zoobenthos survey of the Pantanal, Mato Grosso do Sul, Brasil. Bulletin of Biological Assessment and Engineering, vol. 18, no. 3, p. 49-55.

TRIVINHO-STRIXINO, S., CORREIA, LCS. and SONODA, K., 2000. Phytophilous chironomidae (Diptera) and other macroinvertebrates in the ox-bow Infernão Lake (Jatai Ecological Station, Luiz Antonio, SP, Brazil). Revista Brasileira de Biologia, vol. 60 , no. 3, p. 527-535. http://dx.doi.org/10.1590/S003471082000000300018. PMid:11188879 